\title{
Lubelskie Fora Bibliologów, Informatologów i Bibliotekarzy jako przestrzeń dyskusji nad wyzwaniami dla bibliotek w epoce cyfryzacii i nowych mediów
}

DOI: http://dx.doi.org/10.12775/TSB.2016.015

Dodlegająca nieustannym transformacjom rzeczywistość społeczno-kulturowa stawia coraz to nowe wyzwania przed bibliotekami i placówkami informacyjnymi, ich kadrą oraz ośrodkami akademickimi, które kształcą w zakresie bibliologii i informatologii. Kierunki rozwoju i zakres działań bibliotek i ośrodków informacji, różnorodność ról i zadań stojących przed pracownikami sektora informacji, nowoczesna edukacja bibliotekarzy, przeobrażenia infrastruktury bibliotecznej, wykorzystanie nowych technologii w pracy z użytkownikiem - to tylko niektóre z kwestii stanowiących przedmiot konferencji i seminariów organizowanych przez środowisko pracowników książki i informacji naukowej.

Problemy te stanowiły także temat dyskusji w gronie lubelskich bibliologów, informatologów i bibliotekarzy. Platformą dla wymiany doświadczeń i poglądów pomiędzy teoretykami a praktykami stało się forum organizowane przez Instytut Informacji Naukowej i Bibliotekoznawstwa Uniwersytetu Marii Curie-Skłodowskiej w Lublinie [dalej: IINiB UMCS]. Partnerami w przygotowaniu tego przedsięwzięcia są: Biblioteka Główna UMCS, Biblioteka Główna Uniwersytetu Przyrodniczego, Regionalny Ośrodek Informacji Rolniczej w Lublinie, Wojewódzka Biblioteka Publiczna im. Hieronima Łopacińskiego w Lublinie, Miejska Biblioteka Publiczna im. Hieronima Łopacińskiego w Lublinie [dalej: MBP], Ośrodek Książki Obrazkowej „OKO”, Pedagogiczna Biblioteka Wojewódzka im. Komisji Edukacji Narodowej w Lublinie [dalej: PBW].

I Lubelskie Forum Bibliologów, Informatologów i Bibliotekarzy odbyło się 19 marca 2015 r. pod hasłem „Nowoczesna biblioteka - no- 
woczesny bibliotekarz". W wydarzeniu uczestniczyło blisko sto osób reprezentujących biblioteki różnego typu (publiczne, szkolne, pedagogiczne, naukowe), ośrodki informacji i kultury oraz środowisko badaczy książki i bibliotek z Lublina i Lubelszczyzny. Forum stało się okazją do zaprezentowania przykładów dobrych praktyk oraz innowacyjnych form pracy w bibliotekach na tle rozwoju nowych narzędzi komunikacji i rosnących wymagań użytkowników. Uczestnicy i prelegenci mogli wspólnie zastanowić się nad poszerzeniem oferty bibliotecznej w nowoczesny i kreatywny sposób oraz rozważyć kwestię przyszłości zawodu bibliotekarza i bibliotek w cyfrowym świecie.

Spotkanie otworzyły wystąpienia dyrektorów instytucji organizujących forum: prof. dr hab. Marii Judy (IINiB UMCS), mgr Renaty Filipiak (MBP) i mgr Barbary Rzeszutko (PBW). W części plenarnej, prowadzonej przez dr Anitę Has-Tokarz, wystąpiło sześciu prelegentów. Dr Renata Malesa (IINiB UMCS), zajmująca się badaniem roli bibliotek na rynku usług informacyjnych oraz wykorzystaniem nowych technologii ICT w kształtowaniu wizerunku biblioteki i bibliotekarza, przedstawiła referat pt. „Marketing partnerski w działalności współczesnej biblioteki”. Prelegentka odwołała się do koncepcji marketingu rozumianego jako swoista filozofia działania i sposób postrzegania podstawowych zasad, jakimi powinny kierować się współcześnie zarówno przedsiębiorstwa o charakterze biznesowym, jak i usługowym. Zwróciła uwagę, że szczególnego znaczenia w bibliotekarstwie współczesnym nabiera marketing partnerski, którego istota polega na rozwijaniu i utrzymywaniu więzi z uczestnikami rynku, tzn. z klientami i innymi partnerami firmy. W referacie przedstawiono znaczenie marketingu relacji $\mathrm{w}$ działalności bibliotek publicznych, z nastawieniem na małe biblioteki gminne. Placówki te współcześnie zmuszone zostały do odpowiedniego rozpoznawania potrzeb klientów oraz ich właściwego zaspokajania. Aby przetrwać oraz odnieść sukces we współczesnym świecie, małe biblioteki gminne muszą podejmować działania we współpracy z różnymi partnerami, tworząc trwałe związki z nimi oraz klientami.

Mgr Wojciech Olchowski, pedagog medialny współpracujący z Urzędem Miasta Lublin, współautor projektu „Komunikacja dla integracji”, wygłosił referat „Biblioteka - lokalny ośrodek aktywności społecznej”. W wystąpieniu zwrócił uwagę na różnice w zakresie ról pełnionych przez biblioteki działające w środowisku wiejskim i wielkomiejskim. W małych 
miejscowościach zastępują one instytucje kultury, w dużych miastach często są zmuszone z nimi konkurować. Prelegent odwołał się do licznych - jego zdaniem wzorcowych - przykładów organizacji placówek bibliotecznych w krajach skandynawskich i w Wielkiej Brytanii.

Dwa kolejne referaty prezentowali pracownicy MBP w Lublinie. Mgr Katarzyna Poleszak z Filii nr 2 przedstawiła prezentację „Biblioteczny Viral”, w której pokazała możliwości wykorzystania narzędzi marketingu wirusowego w promocji czytelnictwa i usług bibliotecznych. Mgr Grzegorz Woźniak, kierownik lubelskiej mediateki, w referacie „Biblioteka inaczej. Działania mediateki BIBLIO” omówił niestandardowe działania podejmowane przez placówkę, które służą budowaniu marki i kreowaniu pozytywnego wizerunku. Podkreślił, że kreowanie mody na bibliotekę jest zależne od rodzaju placówki (biblioteka miejska, biblioteka uniwersytecka itp.), jednak szkielet mechanizmu oraz cel przyświecający takiemu działaniu powinien być zbliżony dla wszystkich bibliotek. Za przykład działań związanych z budowaniem mody na bibliotekę posłużyła mu macierzysta placówka - Biblioteka Multimedialna Biblio. Prelegent wyeksplikował w wystąpieniu, że każda moda powstaje w oparciu o odpowiedni, interesujący potencjalnego odbiorcę, punkt wyjścia (może być nim przedmiot, osoba, utwór itp.). W przypadku bibliotek jako punkt wyjścia należy przyjąć odpowiednio urządzoną i wyposażoną placówkę, która przyciąga zainteresowanie czytelników oraz trafia w ich potrzeby. Działania składające się na budowanie mody na bibliotekę podzielił na globalne oraz lokalne. Te pierwsze to według niego, wszystkie aktywności mające na celu wzbudzenie i podtrzymanie zainteresowania miejscem. Z kolei drugie polegają na tworzeniu i utrzymywaniu więzi z użytkownikiem. W działaniach globalnych związanych z kreowaniem mody istotną rolę odgrywają projekty mogące podnieść rangę biblioteki, zarówno wśród użytkowników, środowisk opiniotwórczych, samorządowych, jak i mediów. W przypadku Biblio wymienił dwa przykłady: pierwszy to ulokowanie w budynku biblioteki American Corner - centrum informacji o kulturze amerykańskiej, drugi - uznanie otwarcia Biblio Wydarzeniem Kultury 2012 r. w Lublinie.

Następni prelegenci podjęli tematykę wykorzystania nowoczesnych technologii w praktyce bibliotecznej. Wystąpienie mgra Macieja Sztorca z PBW dotyczyło Internetu jako narzędzia promocji bibliotek. Referent podkreślił znaczenie odpowiednio zaprojektowanej strony WWW dla 
reklamy usług bibliotecznych oraz możliwości, jakie oferują serwisy społecznościowe, takie jak Facebook, Twitter czy YouTube. Mgr Kamil Stępień (IINiB UMCS), którego zainteresowania badawcze oscylują wokół zagadnień wizualizacji informacji i funkcjonowania fotografii w przestrzeni sieciowej, zaprezentował referat „Wyszukiwanie obrazem. Nowoczesne trendy w wyszukiwaniu informacji”. Zwrócił w nim uwagę na „lawinowy” przyrost obrazów (fotografii i grafik) w przestrzeni WWW. Przedstawił sposoby, metody i cele, jakie stawia sobie współczesny użytkownik Internetu, wyszukując informacje wizualne w sieci. Pokazał projekty sieciowe opisujące obrazy za pomocą słów kluczowych (w tym tagów) i wyszukiwania „nietekstowe” z użyciem atrybutów wizualnych, takich jak: barwy, odcienie kolorów, kontury, kontrasty, kształty czy wzory obiektów składających się na obraz. Zastanawiał się nad przyszłością wyszukiwania wizualnego, podkreślając jego znaczenie i potencjał dla bibliotek.

W drugiej części forum odbył się panel dyskusyjny „Nowoczesna biblioteka - czyli jaka? O wyznacznikach nowoczesności”/„Nowoczesny bibliotekarz - czyli jaki? Kompetencje szczególnie pożądane”, moderowany przez dr Renatę Malesę, mgra Macieja Sztorca i mgra Grzegorza Woźniaka. Podczas dyskusji poruszono problem wielowymiarowości kategorii „nowoczesność” w kontekście bibliotek. Odniesiono ją do takich sfer, jak architektura i wykorzystanie innowacyjnych technologii, ale również wielość ról i zadań, jakim musi sprostać współczesna placówka biblioteczna. Rozważano kwestie: biblioteki jako interfejsu, jako miejsca public learning, multimedialnego centrum kultury oraz symbolu otwartości i usieciowienia medialnego. Zastanawiając się nad umiejętnościami i kompetencjami nowoczesnego bibliotekarza, uczestnicy dyskusji doszli do wniosku, że musi on dobrze czuć się w różnorodnych rolach: powinien być ekspertem w swojej dziedzinie, menedżerem, negocjatorem, badaczem, operatorem baz danych, planistą, znawcą technologii informacyjnych i zasad przedsiębiorczości, a także psychologiem, opiekunem i nauczycielem, ciągle otwartym na wiedzę i nowe umiejętności ucznia i użytkownika.

Duże zainteresowanie I Forum potwierdziło potrzebę organizowania spotkań konsolidujących środowisko i stwarzających przestrzeń do prowadzenia istotnych dla niego dyskusji. Stało się także asumptem do przygotowania kolejnej edycji forum. 
II Lubelskie Forum Bibliologów, Informatologów i Bibliotekarzy: „Nowoczesne formy pracy w bibliotece - możliwości placówek a potrzeby i oczekiwania użytkowników", w którym uczestniczyło ponad sto dwadzieścia osób, odbyło się 8 października 2015 r. Współczesne biblioteki i placówki informacyjne niewątpliwie podlegają przeobrażeniom. Dotyczy to zarówno pełnionych funkcji społecznych, jak i wielości zadań oraz ról stawianych przed ich pracownikami. Odchodzi się od myślenia o bibliotece tylko i wyłącznie przez pryzmat czytelnictwa (choć nadal jest ono kluczowe). Wychodząc naprzeciw wyzwaniom nowoczesności i oczekiwaniom użytkowników, wiele placówek wzbogaca ofertę o działania związane z nowymi technologiami i animacją kulturalno-społeczną. W dobie szybko zmieniających się potrzeb użytkowników rodzi się pytanie: czy i w jakim zakresie placówki są w stanie im sprostać? Stało się ono kluczowe dla uczestników II Forum.

Spotkanie otworzyły wystąpienia dyrektorów instytucji współorganizujących forum: dr Anity Has-Tokarz (IINiB UMCS), mgr Renaty Filipiak (MBP) i mgr Barbary Rzeszutko (PBW). W części plenarnej, prowadzonej przez dr Anitę Has-Tokarz, zaprezentowano 9 referatów, które dotyczyły nowatorskich działań i rozwiązań w zakresie pracy z użytkownikami bibliotek różnego typu: akademickich, publicznych, pedagogicznych, szkolnych.

Mgr Joanna Tarasiewicz, reprezentująca Pedagogiczną Bibliotekę Wojewódzką, wygłosiła referat na temat: „Aktywna obecność - nowe formy wspomagania placówek edukacyjnych przez PBW im. KEN w Lublinie”. Prelegentka odwołała się do aktualnego „Rozporządzenia MEN w sprawie szczegółowych zasad działania publicznych bibliotek pedagogicznych”, które nakłada na te placówki obowiązek szerszego wspomagania szkół, ośrodków edukacyjnych oraz nauczycieli. Przedstawiła także ofertę swojej macierzystej placówki w tym zakresie, która obejmuje takie formy, jak lekcje biblioteczne, warsztaty dla nauczycieli, przygotowywanie kwerend i zestawień bibliograficznych, ale także konkursy, wystawy prac plastycznych, imprezy czytelnicze, spotkania autorskie, indywidualne konsultacje i szkolenia dla nauczycieli.

Przedstawicielki Biblioteki Głównej Uniwersytetu Przyrodniczego w Lublinie, dr Paulina Studzińska-Jaksim, mgr Monika Szarama i mgr Maria Boćkowska, w referacie „Zdiagnozowanie - zaangażowanie - zmiana. Oczekiwania użytkowników a możliwości nowoczesnej biblioteki” omó- 
wiły wyniki ankiety dotyczącej poziomu satysfakcji użytkowników z usług ich placówki. Z badań wynika, że poziom ten jest dosyć wysoki, jednak mimo nowoczesnego budynku i ciągle rozszerzanego repertuaru usług oczekiwania odbiorców stale rosną. Zrodziło to pytanie, czy biblioteka jest w stanie im sprostać?

Bibliotekę Uniwersytecką UMCS reprezentowała zastępca dyrektora mgr Urszula Poślada, która w wystąpieniu „Z Biblioteką dookoła świata” omówiła nowe narzędzia wyszukiwania oferowane użytkownikom przez placówkę - multiwyszukiwarkę naukową PRIMO i program zdalnego dostępu do komercyjnych źródeł elektronicznych - HAN. Multiwyszukiwarka PRIMO - umożliwiająca równoczesne przeszukiwanie katalogu komputerowego Biblioteki Cyfrowej UMCS, licencjonowanych zasobów cyfrowych zakupionych przez UMCS (elektronicznych książek i czasopism, bibliograficznych, faktograficznych i pełnotekstowych baz danych) oraz zasobów dostępnych w modelu Open Access - jest modułem Lubelskiej Biblioteki Wirtualnej, która integruje przeszukiwanie zasobów cyfrowych bibliotek Lublina i Lubelszczyzny. Dzięki zakupionemu systemowi HAN użytkownicy biblioteki mogą korzystać z licencjonowanych zasobów elektronicznych poza siecią uniwersytecką, np. z komputerów domowych.

Kolejne cztery referaty prezentowały nowoczesne formy pracy z użytkownikiem bibliotek publicznych. Mgr Renata Filipiak przygotowała prezentację „Twórczo i niebanalnie, czyli o metodach pracy z czytelnikiem w Miejskiej Bibliotece Publicznej w Lublinie". Referentka przedstawiła w niej szereg niekonwencjonalnych form pracy z różnymi kategoriami użytkowników (dzieci, osoby wykluczone, seniorzy), jak: wirtualne graffiti, Akademia Seniora, konkursy gier planszowych, „Biblioteczne wtorki z muzyką klasyczną", „Kino dla czytelnika - z literaturą w tle”, wystawy, wernisaże, warsztaty, konkursy itp.

Mgr Małgorzata Zińczuk z Miejskiej Biblioteki Publicznej we Włodawie w referacie „Biblioteczny Przystanek na Szlaku 7 cudów Funduszy Europejskich - biblioteka przyjazna nie tylko dzieciom" pokazała korzyści wynikające $\mathrm{z}$ aplikowania przez biblioteki o fundusze europejskie. Omówiła realizację projektu gminy miejskiej Włodawa „Poprawa dostępności do zasobów miejskiej biblioteki publicznej dla mieszkańców Włodawy”. Zaprezentowała nowe logo i nowatorską ideę SMO - Słowo - Muzyka - Obraz, wokół której skupia się przestrzeń edukacyjno-kulturowa włodawskiej biblioteki. Przedstawiła także działalność biblioteki w 2014 r., ze 
szczególnym uwzględnieniem realizacji form pracy z użyciem nowoczesnych technologii i narzędzi adresowanych do użytkowników w różnym wieku. Wystąpienie zakończyło się dedykacją filmowo-muzyczną dla bibliotekarzy Lubelszczyzny od najmłodszej publiczności czytelniczej Włodawy. Teledysk „Biblioteczny song” wywołał bardzo żywą reakcję zebranych.

Mgr Mariola Szupiluk z Multimedialnej Biblioteki dla Dzieci i Młodzieży w Białej Podlaskiej BARWNA omówiła nowoczesne formy pracy z najmłodszymi czytelnikami. To biblioteka, która oferuje zajęcia głównie dla dzieci i młodzieży (od kilkumiesięcznych, poprzez przedszkolaki, uczniów szkół podstawowych, aż do gimnazjalistów), ale także dla rodziców, nauczycieli, pedagogów. Placówka istnieje od 2012 r. dzięki finansowemu wsparciu z Unii Europejskiej, Urzędu Marszałkowskiego w Lublinie i Urzędu Miasta Biała Podlaska. Jej głównym założeniem jest propagowanie „barwnej strony życia”, którą mogą zapewnić książki i różnorodne media. Jej „barwność” to także atrakcyjne wnętrza, kolory poszczególnych działów i otwarci bibliotekarze.

0 intermediach jako alternatywnej formie aktywizacji młodych czytelników opowiedziała mgr Justyna Kondrat z mediateki Biblio w Lublinie. Podkreśliła rolę niestandardowego, nowoczesnego wystroju placówki w przyciąganiu uwagi dzieci i młodzieży. Wnętrze biblioteki wykonano w klimacie skateparkowym, do czego nawiązują siedziska w kształcie ramp, stylizowane biurka komputerowe, beczki występujące w roli stolików itp. Pomieszczenie ma klimatyzację, co zdecydowanie uprzyjemnia korzystanie $\mathrm{z}$ biblioteki w upalne dni. W Biblio użytkownicy mają do swej dyspozycji osiem stanowisk komputerowych, w tym dwa stanowiska z urządzeniami typu MAC. Na sali rozlokowano sześć stanowisk odsłuchowych, pozwalających na zapoznanie się z płytą przed wypożyczeniem bądź swobodny relaks przy dźwiękach wybranej muzyki. Dużym zainteresowaniem młodzieży cieszą się stanowiska z konsolami PlayStation 3 oraz X-Box, które w komplecie z 40-calowymi telewizorami sprawdzają się przy prezentacji rozmaitych materiałów oraz pozwalają na zapoznanie się z niestandardowymi i nowatorskimi urządzeniami, takimi jak np. czujnik ruchu. W Biblio nie zabrakło również bardziej wymyślnych urządzeń. Pomocny w rozwoju talentu graficznego, zwłaszcza najmłodszych użytkowników, jest elektroniczny spray, który pozwala na tworzenie interesującego, wirtualnego graffiti. Kompletowane jest 
również rozbudowane stanowisko do obróbki dźwięku, wyposażone w stosowne kontrolery oraz gramofon DJ-ski. Intermedia obecne w placówce pozwalają na opracowanie oferty zajęć szczególnie atrakcyjnych dla przedstawicieli pokolenia „cyfrowych tubylców”.

Następne wystąpienie dotyczyło specyfiki pracy biblioteki szkolnej. Mgr Aneta Szadziewska z Gimnazjum nr 3 w Lublinie przedstawiła prezentację pt. „eTwinning jako sposób na realizację nowoczesnego projektu edukacyjnego”. „eTwinning” to program współpracy bliźniaczych przedszkoli, szkół podstawowych i średnich w Europie za pośrednictwem mediów elektronicznych oraz promowanie szkolenia nauczycieli. Wśród zalet projektu wymienić należy entuzjazm, motywację do nauki i poznawania świata, kreatywność nauczycieli i uczniów, dostosowanie zadań do możliwości każdego ucznia, realizację projektów zgodnie ze zmianami programowymi gimnazjów oraz tworzenie zespołów nauczycieli. Referentka omówiła ponadto możliwości wykorzystania programu w pracy biblioteki szkolnej oraz zaprezentowała wybrane projekty.

Sesję plenarną zakończył referat dra Sebastiana Kotuły (IINiB UMCS), który zaprezentował możliwości implementacji idei open source w bibliotekach. Referent omówił społeczny fenomen ruchu open source, którego celem jest wspieranie i rozwój technologii. Wskazał przykłady zastosowania idei open source, a więc swoistej idei podejścia do wszelkiej działalności twórczej (badawczej, rozwojowej itp.) realizowanej w różnych sferach działalności ludzkiej, w tym w bibliotekach.

W drugiej części forum odbył się panel dyskusyjny „Nowe (?) oczekiwania i potrzeby użytkowników współczesnych bibliotek - czy? i jak? placówki mogą im sprostać" moderowany przez dr Renatę Malesę. Dyskutowano m.in. o kondycji finansowej bibliotek, źródłach pozyskiwania dodatkowych funduszy na działalność, możliwościach poprawy wizerunku bibliotek i bibliotekarzy w oczach użytkowników i decydentów. Zastanawiano się, jak przekonać władze samorządowe i akademickie do inwestowania w biblioteki oraz w jakim kierunku powinny podążać modyfikacje koncepcji kształcenia przyszłych kadr dla bibliotek i placówek informacyjnych. Ze strony uczestników pojawiły się liczne propozycje tematów i problemów, które warto i należałoby poruszyć podczas kolejnych spotkań, jak np. formy popularyzacji czytelnictwa w kontekście „Narodowego Programu Rozwoju Czytelnictwa”, czy kwestia zmiany sposobu postrzegania biblioteki i bibliotekarza w społeczeństwie. 
Uczestnicy konferencji podkreślali zasadność organizowania podobnych spotkań, które umożliwiają wymianę wiedzy i doświadczeń oraz integrację środowiska. Dla IINiB UMCS wydarzenie stało się okazją do zacieśnienia współpracy z pracodawcami i przedyskutowania kwestii dotyczących realizowanego modelu kształcenia. Forum niewątpliwie przyczynia się do scalenia środowiska bibliologów, informatologów i bibliotekarzy z Lublina i Lubelszczyzny. W najbliższym czasie planowane są kolejne, cykliczne spotkania.

Anita Has-Tokarz

Renata Malesa

Instytut Informacji Naukowej i Bibliotekoznawstwa Uniwersytetu Marii Curie-Skłodowskiej w Lublinie

\section{Ogólnopolska Konferencja Naukowa "Z dziejów książki i prasy. Przegląd badań za lata 2013-2015" (Bydgoszcz, 27 listopada 2015 r.)} nia 27 listopada 2015 r. odbyła się III Ogólnopolska Konferencja Naukowa „Z dziejów książki i prasy. Przegląd badań za lata 2013-2015” zorganizowana przez Katedrę Informacji Naukowej i Bibliologii Uniwersytetu Kazimierza Wielkiego w Bydgoszczy. Było to kolejne w tym ośrodku spotkanie historyków książki i prasy i już sam fakt cykliczności przyniósł owoce w postaci referatów będących kontynuacją wcześniejszych opracowań, poszerzeniem lub pogłębieniem badanych tematów. Zaobserwować nawet można było podejmowanie zagadnień zasygnalizowanych na wcześniejszych konferencjach przez innych badaczy, dzięki czemu bydgoskie spotkania stają się rzeczywistym forum komunikacji w nauce. 